\title{
Meet the New Education and Practice Section Editor
}

\author{
Grant J. Rich, PhD, BCTMB, LMT, LSW \\ Practice \& Education Section Editor, IJTMB \\ Juneau, Alaska, USA
}

This article serves as an introduction to Grant $\mathbf{J}$. Rich, PhD LMT BCTMB, the new IJTMB Education and Practice Section Editor, and describes his education and experience.

I am delighted to join IJTMB as Education and Practice Section Editor. I received my PhD in Psychology: Human Development from the University of Chicago, where I was awarded the University Fellowship. I have over twenty years of experience teaching at both the undergraduate and graduate level, both in the USA, and internationally in India and in Cambodia. I am a Fellow of the American Psychological Association and of the Society for the Teaching of Psychology.

A board-certified massage therapist (BCTMB), I have served on medical missions internationally and travelled to over 22 nations. I have an abiding interest in education, and have published numerous articles on the teaching of psychology (e.g., Teaching of Psychology, Journal of Positive Psychology).

I have previously served the profession in such contexts as reviewer for $I J T M B$ and $J B M T$, and as a member of the Foundation's Research Proposal Review Committee. I've served as reviewer for several dozen academic journals, publishers, and professional associations, and currently sit on several editorial boards. In addition to authoring several dozen book chapters and journal articles, and over ninety book reviews, I am also editor of the academic research book, Massage Therapy: The Evidence for Practice (2002). I have published in such journals as the Journal of Bodywork and Movement Therapies, and Massage Therapy Journal, as well as American Psychological Association journals including American
Psychologist and Professional Psychology: Research and Practice.

Currently I am coediting a book in contract entitled Internationalizing the Teaching of Psychology. I am senior editor of the book Pathfinders in International Psychology (2015). From 2010 to 2014, I was editor of APA's International Psychology Bulletin, and I received the 2014 President's Award for Extraordinary Service: APA Division of International Psychology. I have presented at numerous professional conferences in the USA and around the globe, including Africa, Asia, Australia, Europe, North and South America, the Caribbean, and the Middle East.

I look forward to working closely with authors, editors, and Massage Therapy Foundation staff. The $I J T M B$ fills a critical role for our profession, and I am honored to share this mission with you.

In closing, I would like to thank the editorial staff for ensuring a smooth transition to the new IJTMB team, especially to Antony Porcino, Past Executive Editor. I also offer my deep gratitude to Glenn M. Hymel, EdD, LMT, Senior Consulting Editor and Emeritus Founding Executive Editor of IJTMB.

\section{COPYRIGHT}

Published under the CreativeCommons AttributionNonCommercial-NoDerivs 3.0 License.

Corresponding author: Grant J. Rich, $\mathrm{PhD}, \mathrm{BCT}-$ MB, LMT, LSW, Consulting Psychologist, Juneau, Alaska 99801, USA

E-mail: optimalex@aol.com 